\title{
Exploring the Narrative Structure of Greek and Indian Mytho-Fictions: A Comparative Study on Select Works
}

\author{
Rajalakshmi T and S. Ramya \\ Department of English and Foreign Languages, SRM Institute of Science and Technology, India
}

\section{ABSTRACT}

Retellings of mythology have been evolving over the years in their form and content. One such type of retelling is the mytho-fiction. Mytho-fiction is a kind of retelling gaining the interest of young readers today. A mytho-fiction is a blend of myth and fantasy. Unlike the other types of retellings, the 'original' or source myth is not given much importance here. Only a few elements from the source myth, like the mythical characters and their characteristics are retained in the mytho-fictions. Amish Tripathi's Shiva Trilogy and Rick Riordan's Percy Jackson and The Olympians series are good examples of mytho-fictions based on Indian and Greek mythologies, respectively. This paper aims to make a comparative study of two mytho-fictions, one text from each of these series, namely Tripati's The Oath of the Vayuputras (2013) and Riordan's The Last Olympian (2009) to find out the similarities and differences in their narrative structures, in order to trace out a basic pattern in the narrative structures of mytho-fictions.

\section{KEY WORDS: MYTHOLOGY, RETELLING, MYTHO-FICTION, NARRATIVE STRUCTURE, COMPARATIVE STUDY.}

\section{INTRODUCTION}

Mytho-fiction is one of the recently evolved kinds of mythological retelling that is being celebrated both in the east and the west. It uses myth to create a thrilling fantasy fiction, thus combining the features of different genres. This paper compares the narratology of a Greek mytho-fiction with an Indian mytho-fiction to identify the characteristic features of a mytho-fiction. Some popular writers of mytho-fictions are Dan Brown, Rick Riordan, Amish Tripati, Roopa Pai, Ashwin Sanghi, etc.

\section{Observations:}

1. Influence of classical myth: The influence of classical myth is very less in Tripati's Shiva Trilogy and Riordan's Percy Jackson and the Olympians series, when compared to other mythological retellings. A narrative study on one text from each of these series would prove the same. The final novel of Shiva Trilogy, i.e., The Oath of the Vayuputras and the final novel of The Percy Jackson and

Biosc Biotech Res Comm P-ISSN: 0974-6455 E-ISSN: 2321-4007

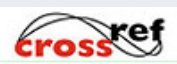

Identifiers and Pagination

Year: 2021 Vol: 14 No (8) Special Issue

Pages: 139-142

This is an open access article under Creative

Commons License Attribn 4.0 Intl (CC-BY). DOI: $h t t p: / / d x . d o i . o r g / 10.21786 / b b r c / 14.8 .31$ the Olympians series, i.e., The Last Olympian, retain a few elements from that of the Classical Mythology.

Such elements are mythological characters and objects and their respective characteristics. However, the plot is otherwise independent from the classical myths. In The Oath of the Vayuputras, numerous mythological characters from the classical Hindu Mythology can be found. Apart from the protagonists like Shiva, Sati, Ganesh, Kartik and Kali, other such mythological characters are Bhrigu, Daksha, Nandi, Parshuram, etc. Their characteristics like Shiva as a yogi, as a destroyer of evil, and Daksha's anger over Shiva's marriage with his daughter Sati, etc., are found in the retelling. But the situations where these characteristics are fitted in are different. Similarly, in The Last Olympian, the Greek mythological characters like Zeus, Athena, Poseidon, Ares, etc., are retained along with their characteristics. But they appear in a purely imaginative plot created by Riordan. As found in the classical myths, the enmity between the gods and titans is a basic theme in the story, but the narration of their war and its cause is different here.

2. Language: The language found in both the texts is modern. Most retellings retain a formal language for godly characters, but the select mytho-fictions defy this standard. In both the mytho-fictions, the language plays an important role in humanising the gods and other 'larger than life' characters. In The Last Olympian, the entire story follows a modern tongue. It is written
Article Information

Received: 04 ${ }^{\text {th }}$ June 2021

Accepted after revision: $20^{\text {th }}$ July 2021 
in first person narration, from the perspective of Percy Jackson, the demi-god hero of the story. The language adds humour and sarcasm to the narration:

'I stared at him, stunned. "Um . . . a god?" Zeus rolled his eyes. "A dimwitted god, apparently. But yes. With the consensus of the entire Council, I can make you immortal. Then I will have to put up with you forever." "Hmm," Ares mused. "That means I can smash him to a pulp as often as I want, and he'll just keep coming back for more. I like this idea"' (Riordan 184-185). In this novel, animals are personified and given dialogues. The chapter titles are longer and sarcastic. For example, the titles of the first two chapters are "I GO CRUISING WITH EXPLOSIVES" (1) and "I MEET SOME FISHY RELATIVES" (13), respectively. Riordan makes even danger sound funny through his language. In The Oath of the Vayuputras, the language is mostly formal and serious except for a few places where Shiva and the other gods are found to use colloquial slangs. The text follows a third person narration: "Parshuram turned towards Ganesh. 'These can be devastating in war, Lord Ganesh. What do you think?'

Ganesh smiled as he borrowed a phrase from his father. "Hell yes!"” (Tripati 74) "Vidyunmali stared at Shiva with barely concealed disgust. 'You were a barbarian when we found you and you are still a barbarian. We Meluhans don't take orders from barbarians!' Chenardhwaj drew his sword. 'Speak with respect to the Neelkanth.' Vidyunmali spat at the governor of Lothal-Maika. 'I don't speak to traitors!' Kali drew her knife out, moving towards Vidyunmali. 'Perhaps you shouldn't speak at all...” (Tripati 170). The chapter titles are short and tothe-point. Two examples of the titles of the chapters in the book are: "Honour Imprisoned" (115) and "God or Country?" (157).

3. Setting: The setting is modern in The Last Olympian. There are two different worlds in the story: one is the mortal world and the other is the mythological world. The story shifts between these two worlds. In The Oath of the Vayuputras, the setting is ancient. The story is set in the times of Ancient Harrappan civilization.

4. Quest: The heroes of both the mytho-fictions are entrusted with a quest. Percy Jackson is supposed to save Mount Olympus from Kronos. Shiva is expected to destroy the Somras manufacturing facility. Both the heroes are supported by their family and friends for fulfilling their destinies. They are also guided by some institution in their deeds. For example, Shiva is guided by the Vasudev Chief Gopal and Percy Jackson is guided by the Gods and Chiron, his teacher. Both the heroes complete their quests successfully for the welfare of the human kind.

5. Theme: The major theme found in both the works is the triumph of good over evil. The evil in The Oath of the Vayuputras is the Somras, since the waste produced during the manufacture of Somras caused fatal illness to many over the generations. The evil in The Last
Olympian is Kronos, the Titan lord, who tries to resurrect himself and vanquish the gods. Another theme similar to both the texts is polytheism. Both Hindu and Greek Mythologies are known for polytheistic ideas and the same is found in these retellings. Dream is used as a theme and a narrative strategy by Riordan and Tripati to inform or prepare the readers for the upcoming events in the story. Dream is also used as a means of communication between characters in both the texts. In The Oath of the Vayuputras, dreams also show flashbacks. "'I had a strange dream.'Hmmm?' 'I dreamt that we were separated"” (Tripati 122).

"Kartik held Parvateshwar's hand. 'General, my mother appeared in a dream to me. She told me to do the right thing. She told me to remember how she lived, and not how she died. Even you know she would have done exactly what I'm trying to do"' (Tripati 284). In The Last Olympian, Riordan further uses dreams to show the other events happening within the plot: "Demigod dreams... ...they're never just dreams. They've got to be visions, omens, and all that other mystical stuff that makes my brain hurt" (Riordan 13). “You see, Percy?” he whispered. "You're running out of time. Do you really think you can beat them without my plan?" His words washed over me as cold as the ocean floor, and my dreams went black' (Riordan 14).

Prophecies are an integrated part of both these mythofictions. In The Last Olympian, there are two oracles delivering prophecies involving the demigods. The prophecies are puzzle-like and the characters in the story struggle to understand their meaning. They warn the characters about the upcoming danger and also offer a hint to overcome the problem but it all depends on how and when the protagonists interpret them. In The Oath of the Vayuputras, the Meluhans go along with the Neelkanth legend as mentioned in The Immortals of Meluha. The legend prophecies that when evil rises to its peak, a blue-throated man will arrive and save all the humans from danger. But The Oath of the Vayuputras shows that a large part of the legend is manually manipulated to make it happen, thus making the legend believable. War is the main action in both the plots. Though there are occasional battles throughout the stories, there is one final battle that decides the victory or loss of the hero. Great attention is given to the nuances of the battle in the narration. Disability is another common theme found in both the works. Differently abled and physically deformed characters are shown to be wellskilled heroes in them, for example, Percy Jackson, Typhon and Grover in The Last Olympian and Kali and Ganesh in The Oath of the Vayuputras.

6. Moral: In The Oath of the Vayuputras, Tripati's attempt to convey philosophies and moral ethics through the story is much evident. Tripati himself reveals such a notion in an interview titled "In Conversation With Amish Tripathi, The Banker-Turned-Writer Making Mythology Cool Again": "According to ancient beliefs, a book without some philosophy is like a body without its soul. I strongly believe in this and hence, I do try to 
include some kind of philosophy or deeper message in my books. Also, I find mythology to be one of the best sources of philosophy. The roots of the word 'mythology' lie in the Greek word 'mythos' which denotes a story or set of stories having a significant truth, philosophy or meaning" (Tripati, The Better India). In The Last Olympian, one does find moral ethics implanted in the story but, Riordan seems to focus more on the idea of entertaining the readers and encouraging the children with dyslexia and ADHD. As mentioned in his blog, he came up with his first mytho-fiction as he ran out of Greek stories to tell his dyslexic son Haley, who showed much interest in Greek mythology.

7. Plot: Because of themes like quest and war, the plots of both the mytho-fictions are action-packed and explorative in nature. Readers are naturally thrilled as the protagonists journey towards fulfilling their quest.

8. God as a position: In both the stories, being a god is almost like playing a role, a role of a powerful being. In The Last Olympian, the readers find the gods struggling to retain their position, and the hero Percy refuses the position of a god given to him as a reward. Only their seats at Mount Olympus gives the gods their power. In The Oath of the Vayuputras, Shiva is acknowledged as a god because of his thoughts and actions. He proves everyone that he is worthy of being a 'Mahadev' even though it is not a position he chose voluntarily. Shiva himself worships other gods like Ram and Rudra, who were again humans who attained the position of god through their selfless thoughts and deeds.

9. Anthropomorphism: It is found in both the works. The gods of The Last Olympian are much more humanised than that of The Oath of the Vayuputras because of qualities like jealousy, anger, grudge, etc., while Shiva carries only guilt and anger. In The Last Olympian, apart from their language, humanly emotions and flawed attitudes, the clothing of the gods is another attempt at humanizing and modernizing them: "My dad, Poseidon, was standing knee-deep in the surf, wearing his typical Bermuda shorts, beat-up cap, and a real subtle pink-andgreen Tommy Bahama shirt” (198).

During this humanization, Riordan balances the stature of the gods by professing them with extra-ordinary powers of which even the demigod heroes are afraid. He also uses imageries like the thunderbolt when Zeus is angry, the sound of a conch to announce Poseidon's arrival, etc., to make sure that he does not disrupt their powerful images while trying to give them a humanly and modern representation. The same applies for Shiva and Sati in The Oath of the Vayuputras. Even though they are put through humanly emotions and struggles, their skills and conduct keep them on a pedestal higher than that of other characters, to justify how they attained the position of gods.

10. End on a positive note: In both the stories, the 'good' side suffers huge losses. The loss of Sati in The Oath of the Vayuputras and the loss of Beckendorf, Beauregard,
Castellan and many others in The Last Olympian affect the rest of the characters badly. However, both the works end by giving a hope for the future generation. The characters try to reduce the damage caused by the war, then make way for the smooth flow of life for the future generation and make sure that the earlier problems do not repeat for another few centuries.

\section{CONCLUSION}

This paper tries to find a common pattern followed in the narration of mytho-fictions by comparing and contrasting different narrative strategies and literary elements found in the select texts. It is deduced from the study that, mytho-fictions tend to have the discussed elements and strategies. However, the study does not make any claim that the presence of these elements is essential to call a work a mytho-fiction.

From the study, it is understood that mytho-fictions, whether influenced by Greek or Indian Mythology, adhere to a few or all of the following characteristics:

a) Minimal influence of classical myths

b) Modern language or setting

c) Heroes entrusted with a quest

d) Support of friends, family and guide for the heroes

e) Triumph of good over evil

f) Anthropomorphism

g) Prophecies governing the plot

h) Importance to duels, battles and wars

i) Governed by morals and philosophies

j) Element of curiosity and surprise

k) Optimistic end, in spite of huge losses

l) Use of dream as a narrative technique

m) God as a position/status

n) Humorous and sarcastic dialogues

In the select mytho-fictions, the story begins with a problem affecting a larger community. The protagonist belongs to the 'good' side and his fate gets entangled with a prophecy in due course of time. In order to fulfill the prophecy, he is entrusted with a quest. With the support of highly-skilled friends, supportive family and experienced guides, the hero begins his journey which is often filled with dangerous battles. The hero faces many obstacles where his choice or decision determines the fate of the entire human kind. In the end, he defeats the evil side and completes his task successfully. The works sign off with the major characters taking measures to stop or slow down the trouble from recurring. On a whole, mytho-fictions carry a kind of critical approach towards classical myths. They make the myths more relevant to readers of today and follow the ideal purpose of literature: to entertain and to educate.

\section{REFERENCES}

Pai, Leena P. (2005) A Passage Through the Mahabharata Re-tellings: Study of Some Contemporary Novels. Diss. Jawaharlal Nehru University, pp. 33. Shodhganga, http://hdl.handle.net/10603/17256. Accessed 3 Oct. 2020. 
Riordan, Rick.( 2013) The Last Olympian. Penguin UK. Riordan, Rick.( 2005) “The Learning-Disabled Hero.” RICK RIORDAN, 2 Sept., https://rickriordan. com/2005/09/the-learning-disabled-hero/. Accessed 25 March 2021.

Tripati, Amish. (2017) "In Conversation With Amish
Tripathi, The Banker-Turned- Writer Making Mythology Cool Again." Interview by Sanchari Pal. The Better India, 26 Sept., https://www.thebetterindia.com/116730/ amish-tripathi-shiva-trilogy-immortal-india-exclusiveinterview/. Accessed on 20 March 2021.

Tripati, Amish. (2013) The Oath of the Vayuputras. Westland. 